\title{
A knowledge sharing framework in the South African public sector
}

\author{
Author: \\ Peter L. Mkhize \\ Affiliation: \\ ${ }^{1}$ School of Computing, \\ University of South Africa, \\ South Africa \\ Correspondence to: \\ Peter Mkhize

\section{Email:} \\ mkhizpl@unisa.ac.za \\ Postal address: \\ PO Box 392, UNISA 0003, \\ Pretoria, South Africa \\ Dates: \\ Received: 23 May 2014 \\ Accepted: 21 Mar. 2015 \\ Published: 05 June 2015 \\ How to cite this article: \\ Mkhize, P.L., 2015, 'A \\ knowledge sharing \\ framework in the South \\ African public sector', \\ South African Journal of \\ Information Management \\ 17(1), Art. \#620, 10 pages. \\ http://dx.doi.org/10.4102/ \\ sajim.v17i1.620

\section{Copyright:} \\ (C) 2015. The Authors. \\ Licensee: AOSIS \\ OpenJournals. This work is \\ licensed under the Creative \\ Commons Attribution \\ License.
}

Read online:

Scan this QR code with your smart phone or mobile device to read online.
In the knowledge economy, organisations are shifting their investment focus to intellectual capital in order to sustain a competitive advantage in the global marketplace. Organisational survival is increasingly dependent on the organisation's ability to create and distribute knowledge that contributes to the improvement of performance. The purpose of this article is to evaluate individual knowledge-acquisition and sharing practices in the South African public sector. I applied the techniques of grounded theory analysis to extract themes from data that could provide insight into the knowledge sharing that takes place in the South African public sector. Findings revealed that the informal sharing of knowledge takes place in discussion forums within communities of practice through web-based, socially orientated platforms. These communities of practice are widespread throughout the public sector and are established with the purpose of soliciting expert knowledge from those who have been using open-source software successfully.

\section{Introduction}

Innovation and change in an organisation bring about a need to upskill employees in order to keep up with new organisational demands. In the knowledge economy, efficiency and effectiveness are dependent on the organisation's ability to adapt to rapid technological changes. According to Acton and Golden (2003), organisations need to focus on improving their knowledge-acquisition strategy because skills and knowledge become obsolete quickly.

Durst and Wilhelm (2012) assert that knowledge is increasingly becoming a crucial asset for organisations - unlike in the industrial age, where machinery was the most important asset. According to Pacharapha (2012), knowledge resides with individuals in the organisation and becomes an instrument for process improvement whereby processes become more efficient and effective. Knowledge kept in the individual's mind does not contribute to organisational success if it is not shared by other employees within the organisation. In this article, the researcher investigates some of the knowledge sharing practices in the South African public sector.

\section{Problem statement}

Existing skills-training mechanisms are either not used optimally or are failing altogether (Statistics South Africa 2010). Pacharapha (2012) suggests that some individuals in the workforce possess knowledge which could be useful in the improvement of service delivery. Skills transfer from the individuals who have such skills to other employees organisation-wide entails a challenge. Individuals' knowledge does not help the public sector because it could be lost if such individuals leave the organisation through death, retirement or resignation.

The diffusion of knowledge through social media is growing fast in South Africa and other African countries (World Wide Worx 2012). In South Africa, many people have widely adopted social media for social interaction. World Wide Worx (2014) reports show that social media and instant messaging usage has grown exponentially in South Africa, mentioning one of the fastest growing mobile applications such as WhatsApp. Its usage is expected to grow to $63 \%$ amongst adults within a year from the date of the report. Despite diffusion through social media, which enables instant collaboration at a minimal cost, social media are not used to facilitate knowledge sharing in the workplace. In this study, the researchers investigate the potential application of social media to share knowledge in the workplace with a specific focus on the biggest employer in the country - the public sector.

\section{Knowledge sharing}

According to Andreeva and Kianto (2012), organisations in the global knowledge economy depend on the ability to acquire and share knowledge in order to gain a competitive advantage. In an organisation, there could be individuals who possess valuable knowledge, but individual 
knowledge is not a competitive advantage for the organisation if it is not shared with other relevant stakeholders (Crane 2012). According to Alavi and Leidner (1999), knowledge sharing enables an entire organisation to gain competitive knowledge and improve its productivity.

Knowledge transfer takes place between individuals and teams (Durst \& Wilhem 2012). It could be technical knowledge that is important for functional departments (Mueller 2012). It is imperative to note the fact that every bit of knowledge that could improve business performance is critical, whether it resides within individuals' minds or is shared by teams in departments (Schuima 2012).

Organisations that wish to facilitate knowledge sharing between individuals and teams must be cognisant of the type of knowledge involved. Polanyi (1966) distinguishes between two types of knowledge. The first type is tacit knowledge, characterised by difficulty to articulate and codify. Tacit knowledge is usually acquired through apprenticeship and extended time with experts. Moreover, this type of knowledge is key to the development of competitive advantage as competitors would usually struggle to cope (Nonaka, Von Krogh \& Voelpel 2006). Conversely, explicit knowledge, Polanyi's second type of knowledge, is easy to codify and to express in an understandable format. According to Nonaka (1994), this type of knowledge can be expressed through traditional learning methods. It will then be useful to discuss knowledge conversion in the following section by discussing the manipulation of tacit and explicit knowledge.

\section{Knowledge conversion}

Nonaka (1994) proposed socialisation, externalisation, combination and internalisation(SECI) as modes of knowledge conversion. These modes are important for organisations that intend to extend their competitive advantage by ensuring that tacit knowledge in the minds of a few is shared within the organisation. Knowledge conversion is important to enable knowledge creation, sharing and retention, especially in the economic sectors that are experiencing a brain drain (Kraak 2004). It is then important to heed Jarrar's (2002) warning that intellectual capital is replacing finance, commodities and natural resources in order to keep up with the rapidly evolving global knowledge economy.

It is important to note that knowledge conversion is also critical as an enabler of dissemination of knowledge within the organisation in order to ensure that tacit knowledge, which resides in the minds of individual employees, can be transferred throughout the organisation (Nonaka \& Takeuchi 1995). In line with the SECI modes of knowledge conversion, the public sector needs to create an environment that enables interplay between individuals in the organisations, sharing tacit knowledge through mechanisms such as observation and imitation (Lottering \& Dick 2012). According to Martin and Martin (2011), sharing tacit knowledge requires a high level of socialisation that could also involve personal experience and close physical proximity while work is being done. It may even imply building and managing emotional relationships.

Nonaka and Takeuchi (1995) also argue that tacit knowledge can be converted into explicit knowledge through iterative social interaction, and explicit knowledge can be transferred to others in the organisation through a social medium. Explicit knowledge is articulative and can be transferred by electronic media. Meetings and traditional workshops can be used to reconfigure and reconceptualise existing knowledge in the combination mode (Chatti 2012). Externalisation enables articulation of tacit knowledge to explicit knowledge through social interaction (Sowe, Stamelos \& Angelis 2008) where individuals involved in the creation of knowledge have to spend extensive amounts of time engaging in mutual interaction (Silva et al. 2012). Internalisation, however, relates converting explicit knowledge into tacit knowledge (Wang, Yang \& Chou 2008). According to Jeon, Kim and Koh (2011), knowledge sharing initiatives should be organised into communities of practice to create a space where individuals with common interests in the subject matter can interact.

\section{Communities of practice}

Balcaen and Hirtz (2007) argue that online-based knowledge sharing promotes critical thinking. Employees participating in online communities have the advantage of engaging the subject of interest critically, especially when they are encouraged to learn independently and work interdependently because they bound by a social contract. Kanuka and Garrison (2004) claim that collaborative, yet reflective, learning has a great potential for facilitating critical thinking, which, in turn, would enable a learning organisation to facilitate the transfer and creation of skills and knowledge. Critical thinking is encouraged within communities of practice as major players in the industry would be able to share insight with employees who also aspire to be experts in their field of interest (Balcaen \& Hirtz 2007).

Within a community of practice, knowledge is socially constructed by the group of participants, who weigh each contribution in order to add value to the discussion (Salmon 2002). Each participant in the community of practice is free to make a contribution towards a solution to the problem or to a subject of concern amongst members of the community. Contributors to the discussion and debate become engaged in the debate until consensus is reached, and the agreed solution remains tentative until a better solution comes along (Wenger \& Snyder 2000). The facilitator has to be there to ensure that the discussions are not diverted towards the wrong direction and to redirect the discussions, if necessary (Levinsen 2006). In order to realise the success of a community of practice, the sponsor of an online community takes into account participants' demographic characteristics such as culture and economic background. This provides insight into participants' inclinations and preferences so that they can customise knowledge sharing in order to achieve success. Knowledge of participants' demographics can help with 
initiating collaborative engagement where every member of the community can equally contribute.

\section{Collaborative engagement}

Zhu, Valke and Schellens (2009) argue that collaborative engagement is shaped and guided by the fundamentals of the social constructivist paradigm. In this paradigm, collaborative engagement enables the co-creation of knowledge by active participants as they explore the concept of interest (Glover, Hardaker \& Xu 2004). Collaborative engagement is carried out through social interaction at group level, based on interdependence between members of the group (Doolan 2013). In the collaborative engagement process, it is imperative that collaborators understand the rules of engagement and the expected outcomes of the process (Bogenrieder \& Van Baalen 2007).

According to Glover et al. (2004), collaborators are convened for a specific goal, which could be planned or unplanned. It is further mentioned that, in the collaboration process, multiple ideas are presented and explored to create a broader mental model of the concept. This is achieved through mutual engagement of the participant in a coordinated effort (Hudson 2003).

The coordinated effort to combine the knowledge and competencies of a group of people enables concept development. This happens on the condition that individuals in a group engage mutually to achieve a specific goal, and everyone is equally responsible for the activities of creating and sharing knowledge (Doolan 2011). All the participants should understand that they are responsible for the creation and dissemination of knowledge to the entire community of practice.

In an attempt to derive a solution, even partly, to the above research problem, I tried to gain insight from the literature into the importance of knowledge sharing. I also looked at models used to facilitate knowledge sharing within the organisation and between organisations. From the literature, I came to understand the role of collaboration in enabling knowledge sharing within communities of practice. In light of the fact that collaboration thrives on socially orientated media, I went on to conduct empirical research in order better to understand the environment in which public sector employees practise knowledge sharing. I also wanted better to understand the application of social media in facilitating knowledge sharing even if it is not formally institutionalised.

\section{Research questions}

In order to achieve the aim of this study, I used the following research questions to provide a guidepost for the subsequent research process:

- What are the key issues that have to be considered in the facilitation of knowledge sharing in the South African public sector?
- How is social media used in the public sector's knowledge sharing practice?

- How do these key constructs interrelate in the design of a knowledge sharing mechanism in the South African public sector?

\section{Research methodology and data analysis}

I chose a qualitative approach within the social constructivist paradigm so that I could gain in-depth understanding of the knowledge practice in the workplace. This is in line with the aim to co-create or co-develop a model with the research participants that could provide a solution to some aspects of the problem. Due to the scarcity of literature and theories that specifically address online knowledge sharing in the South African context, I applied the method of grounded theory analysis within a case-study design (Glaser \& Strauss 1967).

The unit of analysis is service departments that are actively involved in knowledge sharing practices in the public sector. Even though knowledge sharing practices were not formally institutionalised at the time of collecting data, there were pockets of communities of practice that shared ideas informally, using social media platforms such as blogs and group tweets. A theoretical sample was used to ensure that each participant enrolled for this study has the knowledge required to answer research questions. This was achieved with the help of the gatekeeper who works in the public sector. Sampling also involved elements of the snowballing technique as participants identified each other and then referred the researcher to those they knew had the knowledge required to answer the research questions. A combination of theoretical and snowball sampling processes resulted in the enrolment of 11 participants from the Department of Public Administration. These participants are deployed as training agents in various service departments involved in software migration or are people who required specific knowledge training. Some of the interviews had more than one participant per session, which resulted in seven interview transcripts and policy documents that were used for analysis.

The concept of grounded theory and some of its techniques were used as a framework with which to conduct this research. According to Charmaz (2006), the principles of grounded theory are not prescriptive but provide guidelines for the detailed analysis of qualitative data and the generation of theory. In applying grounded theory, I conducted data collection and analysis concurrently because subsequent interview probing is dependent on the analysis results from the previous interview (Strauss \& Corbin 1997).

I developed a case-study protocol, including an interview schedule based on the research questions of the study (Remenyi \& Williams 1998). Questions in the interview schedule could be refined from one interview to another as I became more theoretically sensitive (McCallin 2003; McGhee, Marland \& Atkinson 2007; Strauss \& Corbin 1997). I then 
applied theoretical sampling to find prospective participants who were more likely to give further information or clarity to the questions which might not have been answered by the initial sample (McCallin 2003). All interviews were transcribed by a qualified transcriber and then uploaded into the qualitative data analysis software, ATLAS.ti.

The techniques of grounded theory analysis were applied by conducting open coding to identify codes as they emerged from data. Codes were extracted from each interview transcript, each representing an attached quotation. A bracketing technique was also used to suppress the researcher's preconceived ideas about the researched subject in the coding process (McGhee et al. 2007). Secondly, axial coding was performed in order to categorise emergent codes into families of codes in Atlas. Ti. I then formulated contextual relationships between codes using a relationship network. At this stage of the analysis, I conducted subsequent interviews with new categories in mind. This process was repeated until data saturation was reached. The final stage of analysis was selective coding, which enabled me to formulate conceptual relationship networks between code families in order to create a storyline.

In the discussion of the findings below, I present quotations from transcripts as evidence. In line with Creswell (2007), quotations are presented verbatim in order to honour participants' voices. Some of the quotations may contain grammar errors because they are presented as they were uttered by the participant. In addition to quotations that are used as evidence, I present relationship diagrams that represent a network of codes extracted during the open coding stage.

\section{Discussion of findings}

In this section, I present results of the grounded theory analysis by providing a code of networks, depicting relationships with a specific theme. The analysis entails direct quotation from the interview transcripts and the discussions. The networks were formed in the axial coding phase of the analysis. Every code in the network was linked to a quotation. The numbers in each code depict the groundedness of the code and the relationships with other codes in the hermeneutic unit.

\section{Social technology infusion in the public sector}

According to my observation, collaborative engagement in the public sector takes place in discussion forums which are based on social technology. In line with Rogers (1995), any technology-enabled initiatives should be introduced with technology-infusion concerns in mind.

Participant 1 revealed that most South African (SA) government departments are engulfed by infrastructural deficiencies. Thus, knowledge sharing practices should be designed to be carried out on a technology platform that is compatible and that could optimally exploit available computing resources. Participant 1 asserts that some departments are trying hard to ensure that the technology resources that are available are used to optimal levels.

P1: 'They get a command they will do this, where you sit about 5 minutes for a screen in the Defence Force you will wait for that screen to come down but with the SAPS that's not the situation so that screen not up for your screen for 15 seconds, they say this useless go away and the same with other students outside your infrastructure is a key constraint'.

P6: 'People resist certain technology because it brings in with it a new strange environment that is not even functioning properly. If you want to introduce people into something new entice them with something good, not too different to what they a familiar with'.

Participant 1 also asserted that infusing technology into the knowledge sharing process could be made easy by introducing

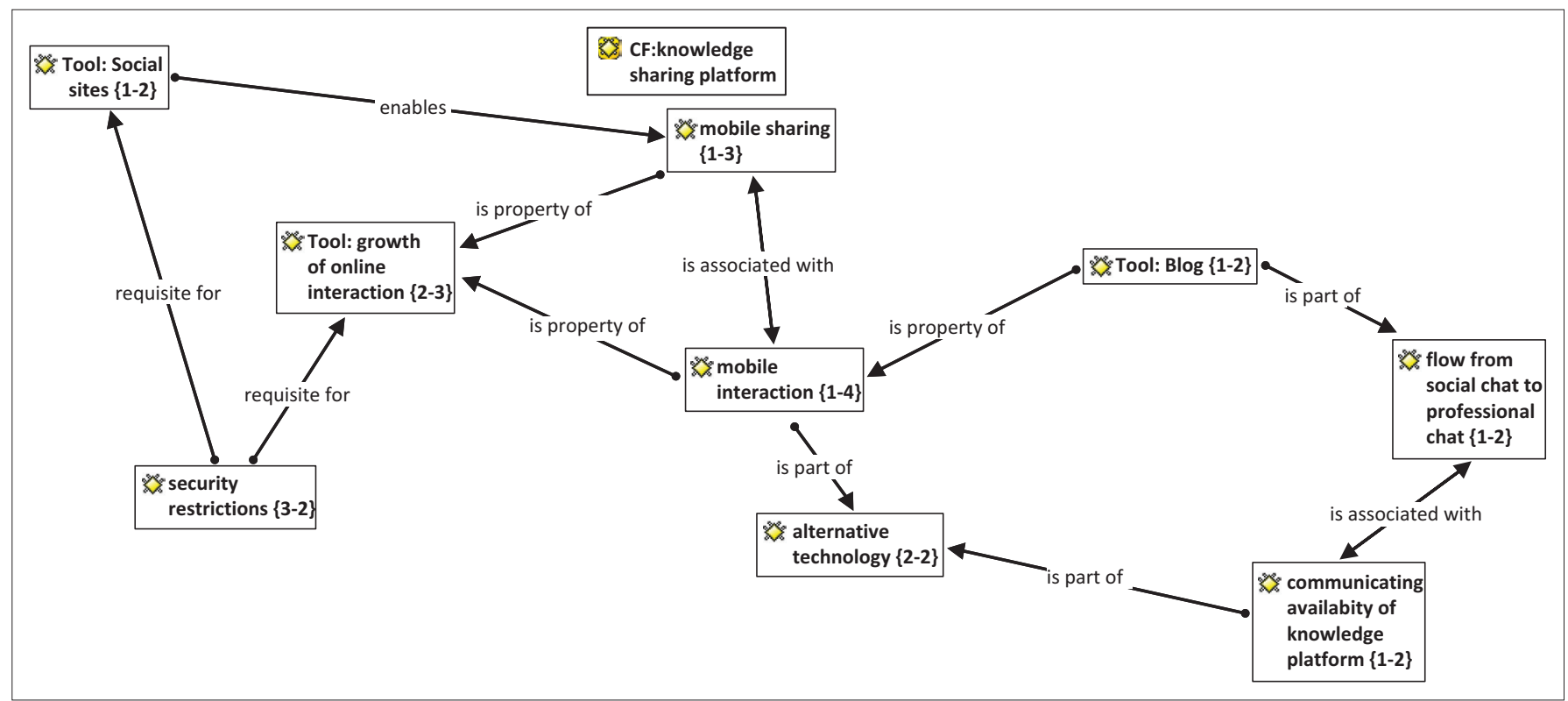

FIGURE 1: Knowledge sharing platform. 
it as a social activity. This can be achieved by incorporating social computing concepts during the introduction of technology in the knowledge sharing process. Many social networks such as blogs, Wikis, Facebook and Twitter have gained popularity in many sectors, such as education, and in other private-sector workplaces (World Wide Worx 2012).

Participant 4 argued that social networks should be used as an introductory strategy in the public sector as many employees are already familiar with and using social networks. He also argued that people make meaningful contributions in the social space with respect to social issues. The same principle can be extrapolated to the knowledge sharing environment. Participant 4 also believed that social networks can be used for continuous learning in the workplace where employees can constantly explore new ideas.

P4: 'It's not, you can pinpoint it down as one little tool, it's actually a migration from ... networks where 1 person contributes to the content through technology making it available and interactive so that lots of people can contribute to that, people they create their own content and that what Web $2.0 \ldots$ is, so with this collaboration thing each one of these tools wiki has got certain pros and cons and set application as blog and set applications as social networking so I think what we've seen in the market ... it's got social networking, it's got micro blogging, it's got blogs, it's got Wikis, it's got RSSP's, it's got ..., it's got everything, so but on the Internet you could get that is just a blogging tool, it's just wiki tool, ... what's a business problem you want to solve, if you know what a problem is what a problem you want to solve ...'

Social networks are important in facilitating an informal knowledge sharing process. Participant 2 suggested that some artificial intelligence should be built into knowledge sharing platforms such as Wiki and blogs to ensure that the correct content is directed to the appropriate employee.
Collaboration in a social space should not be confined to desktop-computer technology but should be extended to mobile technology and other forms of ICT. Therefore, content should be adaptive to different technology platforms such as cellular phones.

P1: 'Adaptation, we need to ... for instance basic one of the ideas being thrown around is M-learning in other words your Mobile Learning, given the fact that the reach of the cell phone is $+-90 \%$ so if you were to adopt to innovate or use mobile as an alternative or an enhancement to e-learning, that will definitely make a big difference, but trying to get $+80 \%$ of South Africa to be connected that is more like a dream'.

P5: 'M-learning ... packages that are out there you know about Blackberry and any other phone that is there but firstly the move will be how many people have cell phones in SA for instance, MTN for instance they will say we've got 17.1 million subscribers'.

According to all participants, South Africa is ready to adopt social computing in the workplace. Participants advise that knowledge sharing should be creative. In this process, one should remain aware of the characteristics of the SA workforce such as socio-economic diversity. Such awareness would help in determining the technological platform that can be used for knowledge sharing purposes, and such platform should be accessible to every employee.

\section{Collaborative engagement}

Collaboration is gaining popularity in both business and academic institutions where collaborators who share resources or work on the same project can exchange information and ideas in order to co-create solutions to eminent problems and to create knowledge. The sharing of information and ideas could be an interaction between individuals within a community of practice or with individuals from outside of the

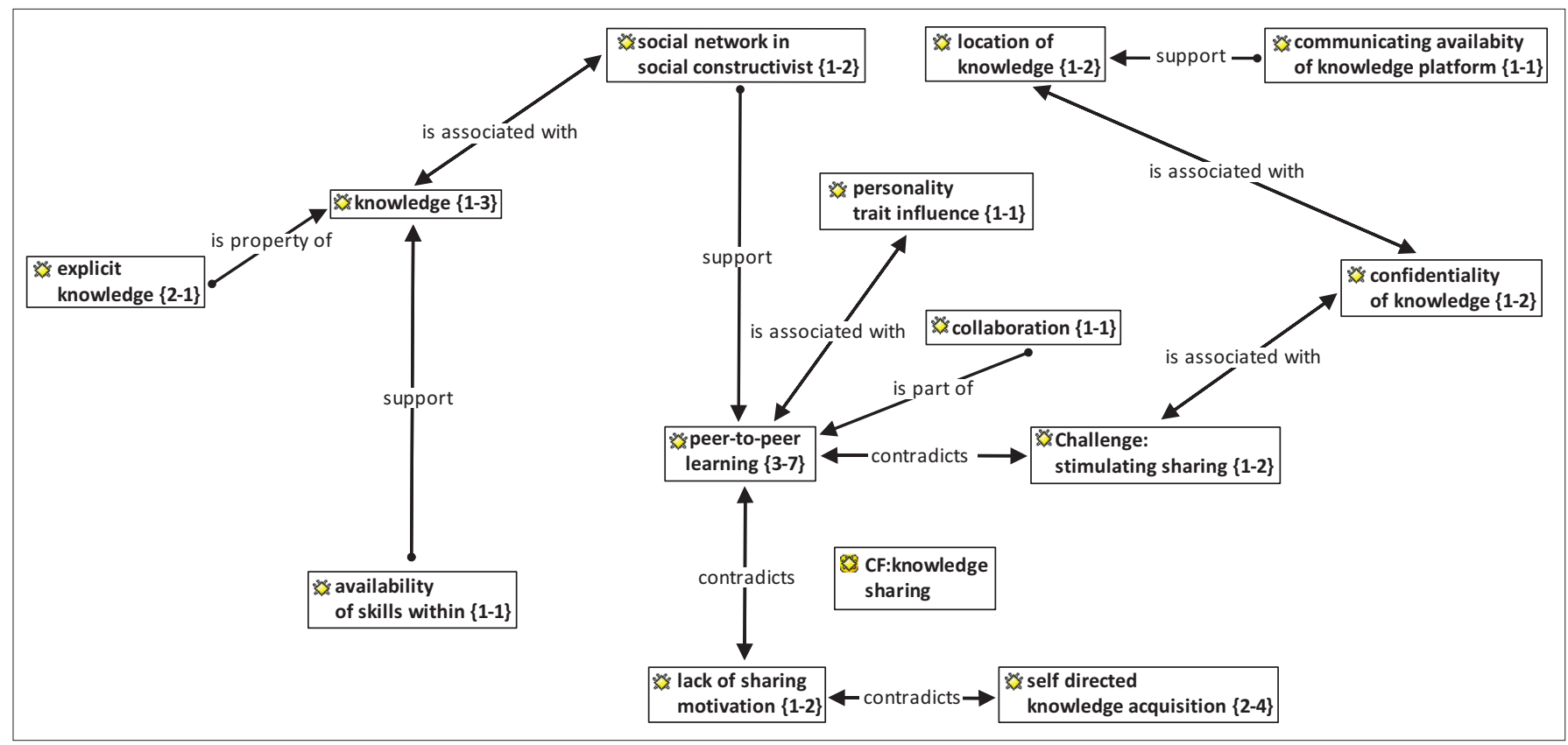

FIGURE 2: Network showing collaborative engagement in the South African public sector. 
community (Mkhize, Huisman \& Lubbe 2011). Figure 2 shows the network of codes that represent activities involved in the development of collaborative experience in the public sector. Some collaboration is informal and some is well-coordinated, depending on the objectives and resources available to community participants (Allan \& Lawless 2005).

Membership of the collaborative forum was by invitation to the qualifying prospective participants, who are expected to make a meaningful contribution to the community. An administrator made a judgement decision about who qualifies to be a participant and then allowed them to join the group that discusses a specific topic regarding a new open-source platform.

P4: 'You might be able to invite external people but then you would qualify them, so in that government-wide collaboration we on the administrator, so I set it up I need to say who's in and who's out and then they would do the same with that'.

The collaboration group sometimes invited subject experts from other collaboration forums by going out of the official government discussion group to find people who may make a major contribution in the current issues of concern. The administrator would even go to the extent of scouting on the social networks to find bloggers who might be experts on a specific subject:

P4: 'Say I was a local developer in SA I would do 1 of 2 things. I would either see if there's existing forums linked in specific groups that are discussing that specific topic, it is possible that those groups won't be focused enough or there might ... but you've got specific needs, what I'll do then is I'll create my own group I'll choose a certain media like I would say I'm going on Facebook or I'm going on this, I would find something that's more like a super cool the kind of personalities that use that, ... I would find something that is suited to my community, having more technical or whatever and then I would start extending that network ... the thinkers in that area and I would extend an invite to that somebody that writing a blog that's ... or start talking to that network and say who are the real experts in open source migration'.

Inviting renowned experts in a certain field allowed the administrator to create a ripple effect by attracting the experts' followers into their discussion forum. Although collaborating groups would need outside experts' contributions to the discussions and debates on issues of concern, it is still important to maintain confidentiality:

P4: 'Think it's just about the confidentiality of the information, say you are in government you typically want to control whoever joins cause you might discuss strategies, communication strategies, things that you want to first vet with different stakeholders before you bring them to the public so in that case you will firstly have the private network'.

As a result, administrators have to be careful in their selection of new members and ensure that confidential information is not openly discussed in the forums. This is to avoid exposure of government's strategies and operational plans.

Participant 5 suggested that a collaborative forum should apply the same model as was applied by early collaborators in government but now with the guidance of an expert to facilitate engagement and debate about topical issues in open-source migration. Through engagement, collaborators would be able to deduce meaning from or come to agreement about new solutions, which could be an extension of existing knowledge. In setting up collaboration, instructional designers can explore the application of technology in facilitating online collaboration. Participant 4 pointed out that Moodle is an effective and efficient collaborative tool for the SITA collaboration group: 'Within Moodle there are some kinds of collaboration or that kind of functionality that you can use and we kinda put them into our project'.

Moodle is an open-source application that can be acquired free of charge. This means easy access and affordability for collaborators. Besides, Moodle incorporates even extended pedagogical features that can be used for the administration and management of the knowledge exchange process.

Instructional designers are facing the task of converting pure collaborative activities into a knowledge transfer mechanism and enabling an environment where knowledge transfer practice can be modelled around the existing collaborative instructional strategy. In doing so, it can ease tensions between management and employees regarding the use of social networks in the office because a formalised collaborative instructional strategy could be institutionalised and then form part of the institutional policy.

\section{Learning by discovery within a community}

Some of the participants quoted in the discussion above also mentioned or implied communities of practice $(\mathrm{CoP})$. Figure 3 shows the CoP theme: I shall discuss a concept that seems to be prominent in the transcripts and which is directly related to communities of practice, namely learning by discovery.

Learning by discovery in a community starts with the creation of the community where learners or employees who share common interests converge to discuss critical issues on a specific topic. Participant 4, who administrates the collaboration forum for government collaboration groups, suggested that collaboration should be designed for free social platforms such as Google or any other Web2.0 platform where an instructional designer can create a group that can share text or video files.

The collaborative forum is secured because of the security and confidentiality requirement. Some of the information shared is sensitive in nature, which means that high security measures should take priority over functionality. However, free social networks can be used where security is not a sensitive issue:

P4: 'Start to building that functionality into the tool so whether you in the design of the course or whether you want employees to interact you need to build the social media the social learning at stake as facilitating the process of learning either by using that functionality in the application you use such as Google or just signing up to any free collaboration 


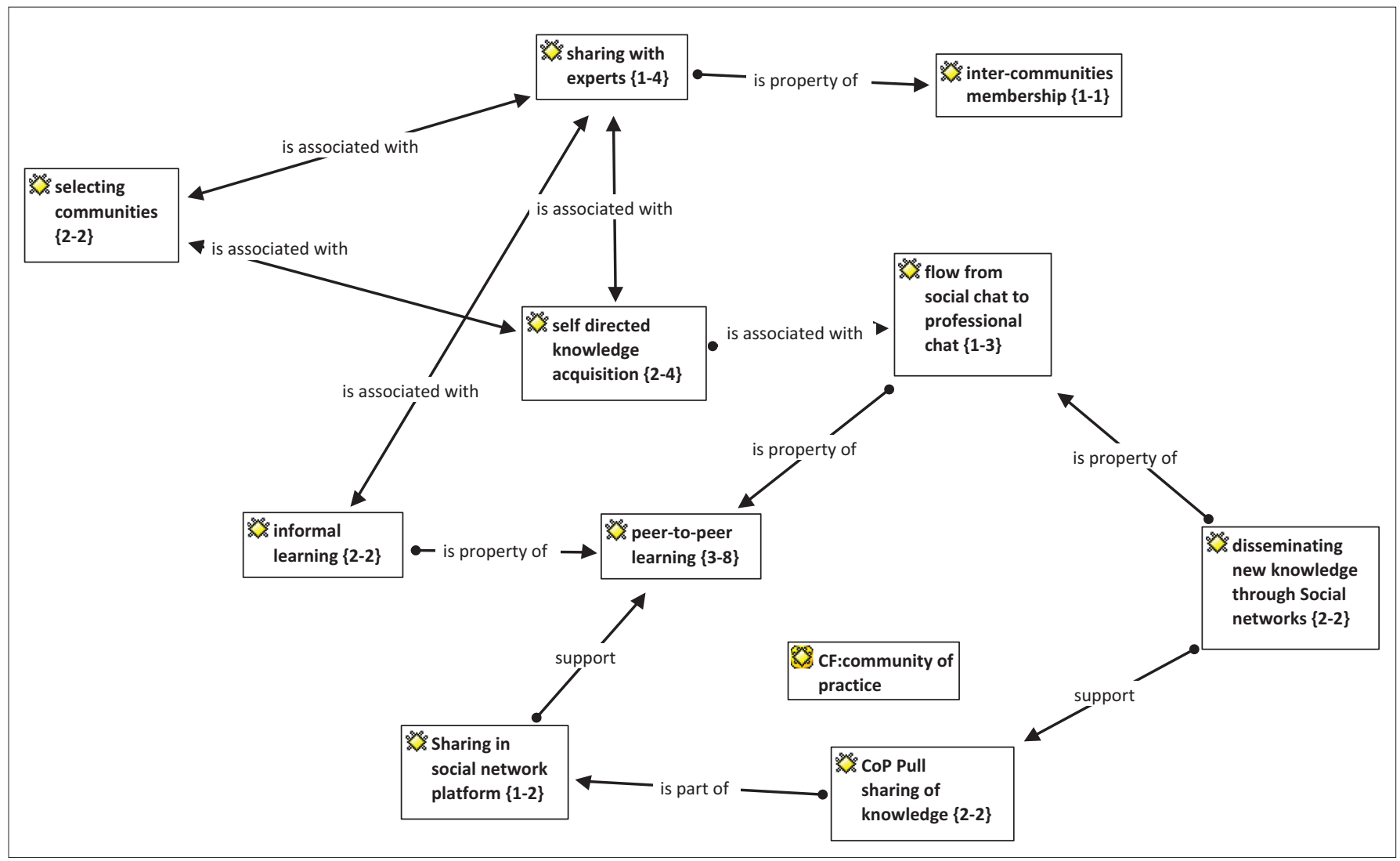

FIGURE 3: Network showing learning through discovery within communities.

tool, create a group then you collaborate so most of these tools they have a model where you can use those functionality for free and those functionalities you can connect with people ... which is making sure that if you doing a course for the military then there's specific requirements around security confidentiality, so that's what SITA is doing in this project, we could use social networks or social tools that are on the Internet but because of that requirement we need to have something that can secure on our firewall and the access of control is very strict'.

Once the security requirements have been established in order to create parameters for membership in the collaboration forum, instructional designers have to consider an instructional strategy that is appropriate for the target audience. In line with the collaborative strategy for government's open-source training, a collaborative environment has to be created within a community of practice. Participant 5 thought that social networks represent the most effective platform for collaborative learning within a specialised group, called a community of practice. Interaction within the community can be standardised into specific time intervals, or openness and flexibility:

P5: 'Community of practice would see people who share common interest in a particular field something, they will be able to seat and collaborate, discuss, move forward and look at the development, to me community those are groups ... they seat every week or every month or people collaborate through that social platform they are all related and they'll say they also contribute to the management of knowledge and knowledge gathering that can be preserved'.
In these communities, members get to share their experiences and learn from those who have been through the learning curve. That way, members of the community would not have to repeat the same mistakes made by those who have become experts over the years. Less experienced collaborators in the community can learn best practices with regard to a specific trade from more experienced community members without going through trial and error. The sharing of information and knowledge enables all concerned to learn new skills to solve persisting problems:

P4: 'Think the main thing about collaboration in government is the culture is pretty much ... so everybody is busy with their own stuff, fighting their own battles and not knowing that another department has maybe kinda a step further in a particular area and they basically got a better solution, so collaboration for us is about creating the tool that can connect these people so that they can form groups, networks of interests and can become aware of other projects, other best practices, other people that have gone through the learning curve, that have got skills'.

A collaborative environment allows for the co-creation of knowledge, based on the collective and agreed interpretation of the studied phenomenon. As members of the community of practice engage one another in a collaborative environment, different forms of expertise interplay into the development of new models that emerge from the convergence of ideas. This is eminent where communities are interlinked in order to engage in issues of common interest, even though communicating individuals might belong to separate communities: 
P4: 'Collaboration in terms of the different roles, to ..., and that what's exciting us, getting together to work out a solution for the government we've had architects, we've had business analysts, we've had the now the content developers as where I'm coming from, we've got the technology architects for government and then we've got change managers who are also involved from beginning to end although they are observing what is coming up first more than anything'.

Members of SITA's collaboration group are not restricted to one community of practice: They can join multiple communities of practice. In that way, one can find communities of practice interlinked by dual membership. Those members with dual membership can source some input from peers of the other community where specialised expertise is required to solve a specialised problem - such as that of anti-corruption:

P2: 'More of the discussion forum and semi-informal course that is being run, the course is called anti-corruption, so it's just more of a discussion forum, we calling in experts from time to time to give more information on how to deal with corruption and so on'.

A collaborative environment encourages the exchange of ideas and knowledge amongst learners or employees within a community of practice. This enables learners or employees to learn through discovery. Participants in the knowledge exchange do not have to enrol for a formal classroom course and then expect the lecturer to present learning material to them while they become passive recipients of knowledge. Rather, they actively engage each other on important issues or concepts relating to the current situation, which makes it easier to find direct and relevant solutions.

\section{Proposed framework}

Figure 4 shows a proposed framework that could provide conceptual insight into the design and development of a knowledge sharing mechanism in the public sector. It also shows that the knowledge sharing process takes place within the social constructivist paradigm, which means that knowledge is created through social interaction, and everybody involved equally contributes to the creation of knowledge.

The creation and sharing of knowledge in the public sector is facilitated through collaborative engagement that takes place within communities of practice. Subjects of discussion are proposed to the communities, and members of the communities then apply collaborative strategies to openly discuss, analyse

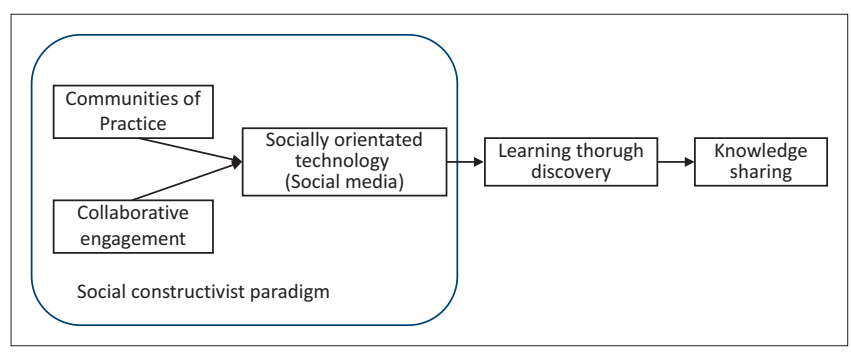

FIGURE 4: Conceptual framework for knowledge transfer in SA public sector. and evaluate issues of interest to the community. The process enables learning through discovery as members discover new meanings to current problems. The definition of 'new meaning' is the product of social engagement between the novices and expert employees who openly share knowledge and ideas for the purpose of knowledge development and improving institutional performance.

Knowledge agents in the public sector are already operating within the social constructivist paradigm to allow for social engagement between all parties involved in the knowledge sharing process. They openly debate the extension of their current knowledge as new perspectives emerge from new employees, and both novices and experts learn from one another.

\section{Contribution of the study}

Through this study, I sought to make a theoretical and practical contribution to knowledge sharing practices. In order to eliminate skills challenges, organisations need to create an environment for the instant acquisition of skills. Otherwise, they would miss out on opportunities made possible by the rapidly changing business environment. The rapidity of change in the business environment could be attributed to rapidly changing technology and other factors beyond the control of organisational personnel. However, an organisation such as the public sector can cope with rapid change emanating from both the global and local business environment if personnel could acquire sets of skills required to face changes.

This study also contributes to knowledge practice in the SA public sector by explicating important factors that knowledge agents should take into account when facilitating knowledge sharing initiatives geared towards improved performance (Matlhape \& Lessing 2002). Amongst other factors, social media could enable flexible learning, collaborative learning and just-in-time, just-in-context and lifelong learning. Social media could also enhance employees' access to knowledge in already flourishing and easy-to-use technology. This is important for both business practice and academia as the framework above could be applied to provide predictive and explanatory value to the theoretical development of knowledge sharing practices in the South African public sector as the biggest employer in the country. According to Acton and Golden (2003), employees should not dread a knowledge-acquisition initiative but, instead, jubilantly look forward to exciting engagement activities that are made possible by social media.

It is important to note that South Africa and Africa as a whole are said to be engulfed by a digital gap in terms of Internet access and computer literacy (Ziemba, Papaj \& Zelazny 2013). However, the social media diffusion in South Africa proves that people do access the Internet and do use computers if they are motivated by social needs, which make a socially orientated platform more attractive as a knowledge sharing platform (Horton \& Horton 2003; World Wide Worx 2012; World Wide Worx 2014). 
Organisational leaders should start to recognise the impact of social networks, which forms the basis of socially orientated instructional technology as was evident in the London riot of October 2011 where the youth organised themselves, using social media, and brought London to a standstill (Baker 2011; Tonkin, Pfeiffer \& Tourte 2012). Socially orientated instructional technology is as powerful in facilitating knowledge sharing in the workplace (World Wide Worx 2014).

\section{Conclusion}

This study set out to determine key concepts that have to be considered in the facilitation of a knowledge sharing mechanism in the public sector. The results of the case study revealed that public sector employees are engaging in not-yet institutionalised but effective knowledge sharing initiatives. Amongst the themes that emerged from a grounded theory analysis are the following: collaborative engagement, communities of practice, learning through discovery and the co-creation of meaning. Some of these themes are sub-themes embedded in the themes discussed above.

Despite the existence of comprehensive learning programmes, it is important to formulate guidelines for knowledge sharing that can be transferable to or adapted by different stakeholders in the public sector when knowledge transfer is needed. A limitation to this study is the fact that results cannot be generalised to the entire population because it was a qualitative study. However, the results are transferable to a similar environment (Denzin \& Lincoln 2011).

\section{Acknowledgements Competing interests}

The author declares that he has no financial or personal relationships which may have inappropriately influenced him in writing this article.

\section{References}

Acton, T. \& Golden, W., 2003, 'Training the knowledge worker: A descriptive study of training practices in Irish software companies', Journal of European Industria Training 27(2/3/4), 137-146.

Alavi, M. \& Leidner, D.E., 1999, 'Knowledge management systems: Issues, challenges, and benefits', Communications of Association of Information Systems 1(7).

Allan, J. \& Lawless, N., 2005, 'Learning through online collaboration by SME staff: A scoping investigation into likely team-role stressors', Education + Training 47(8/9), 653-664.

Andreeva, T. \& Kianto, A., 2012, 'Does knowledge management really matter? Linking knowledge management practices, competitiveness and economic performance', Journal of Knowledge Management 16(4), 617-636. http://dx.doi. org/10.1108/13673271211246185

Baker, S.A., 2011, 'The mediated crowd: New social media and new forms of rioting', Sociological Research Online 16(4), 21. http://dx.doi.org/10.5153/sro.2553

Balcaen, P. \& Hirtz, J., 2007, 'Developing critically thoughtful e-learning communities of practice', proceedings of the 2nd International Conference on e-Learning, 27-28 June 2007, University of British Columbia, Canada, p. 11.

Bogenrieder, I. \& Van Baalen, P., 2007, 'Contested practice: Multiple inclusion in double-knit organizations', Journal of Organizational Change Management 20(4), 579-595. http://dx.doi.org/10.1108/09534810710760090

Charmaz, K., 2006, Constructing grounded theory: A practical guide through qualitative analysis, Sage Publications, Thousand Oaks.

Chatti, M.A., 2012, 'Knowledge management: A personal knowledge network perspective', Journal of Knowledge Management 16(5), 829-844. http://dx.doi. org/10.1108/13673271211262835
Crane, L., 2012, 'Trust me, I'm an expert: Identity construction and knowledge sharing', Journal of Knowledge Management 16(3), 448-460. http://dx.doi. org/10.1108/13673271211238760

Creswell, J.W., 2007, Qualitative inquiry \& research design: Choosing among five approaches, Sage Publications, Thousand Oaks.

Denzin, N.K. \& Lincoln, Y.S., 2011, The SAGE handbook of qualitative research, Sage Publications, Thousand Oaks.

Doolan, M.A., 2011, 'Developing a pedagogy: The role of the tutor in enabling student learning through the use of a wiki', Cutting-edge Technologies in Higher Education 1, 189-205. http://dx.doi.org/10.1108/S2044-9968(2011)0000001012

Doolan, M.A., 2013, 'A pedagogical framework for collaborative learning in a social blended e-Learning context', Cutting-edge Technologies in Higher Education 6 261-285. http://dx.doi.org/10.1108/S2044-9968(2013)000006G012

Durst, S. \& Wilhelm, S., 2012, 'Knowledge management and succession planning in SMEs', Journal of Knowledge Management 16(4) 637-646. http://dx.doi. org/10.1108/13673271211246194

Glaser, B.G. \& Strauss, A.L., 1967, The discovery of grounded theory: Strategies for qualitative research, Aldine de Gruyter, Chicago.

Glover, I., Hardaker, G. \& Xu, Z., 2004, 'Collaborative annotation system environment (CASE) for online learning', Campus-Wide Information Systems 21(2), 72-80. http://dx.doi.org/10.1108/10650740410529501

Horton, W. \& Horton, K., 2003, E-learning tools and technologies: A consumer's guide for trainers, teachers, educators, and instructional designers, John Wiley \& Sons, for trainers,
Chichester.

Hudson, B., 2003, 'Promoting collaboration in an international online learning community', Industrial and Commercial Training 35(3), 88-93. http://dx.doi. org/10.1108/00197850310470294

Jarrar, Y.F., 2002, 'Knowledge management: Learning for organisational experience', Managerial Auditing Journal 17(6) 322-328. http://dx.doi. org/10.1108/02686900210434104

Jeon, S., Kim, Y. \& Koh, J., 2011, 'Individual, social, and organizational contexts for active knowledge sharing in communities of practice', Expert Systems with Application 38, 12423-12431.

Kanuka, H. \& Garrison, D.R., 2004, 'Cognitive presence in online learning', Journal of Computing in Higher Education 15(2), 21-39. http://dx.doi.org/10.1007/BF02940928

Kraak, A., 2004, An overview of South African human resources development, Human Sciences Research Council Press, Cape Town.

Levinsen, K., 2006 'Collaborative on-line teaching: The inevitable path to deep learning and knowledge sharing', Electronic journal of e-learning 4(1), 41-48.

Lottering, F. \& Dick, A.L., 2012, 'Integrating knowledge seeking into knowledge management models and frameworks', South African Journal of Information Management 14(1), 9. http://dx.doi.org/10.4102/sajim.v14i1.515

Martin, E.C. \& Martin, N., 2011, 'The role of organisational factors in combating tacit knowledge loss in organisations', Southern African Business Review 15(1), 49-69.

Matlhape, M. \& Lessing, N., 2002, 'Employees in total quality management', Acta Commercii 2, 21-34.

McCallin, A.M., 2003, 'Designing a grounded theory study: Some practicalities', Nursing in critical care 8(5), 203-208. http://dx.doi.org/10.1046/j.13621017.2003.00033.x

McGhee, G., Marland, G.R. \& Atkinson, J., 2007, 'Grounded theory research: Literature reviewing and reflexivity', Journal of advanced nursing 60(3), 334-342. http:// dx.doi.org/10.1111/j.1365-2648.2007.04436.x

Mkhize, P.L., Huisman, M. \& Lubbe, S., 2011, 'Analysis of collaborative learning as prevalent instructional strategy of South African government elearning practices, proceedings of the 10th European Conference on e-Learning, University of proceedings of the 10th European Conference
Brighton, UK, November 10-11, 2011, pp. 492-501.

Mueller, J., 2012, 'Knowledge sharing between project teams and its cultural antecedents', Journal of Knowledge Management 16(3), 435-447. http://dx.doi. org/10.1108/13673271211238751

Nonaka, I., 1994, 'A dynamic theory of organizational knowledge creation', Organizational Science 5(1), 14-37. http://dx.doi.org/10.1287/orsc.5.1.14

Nonaka, I. \& Takeuchi, H., 1995, The knowledge-creating company: How Japanese companies create the dynamics of innovation, Oxford University Press, New York.

Nonaka, I., Von Krogh, G. \& Voelpel, S., 2006, 'Organizational knowledge creation theory: Evolutionary paths and future advances', Organization Studies 27, 1179. http://dx.doi.org/10.1177/0170840606066312

Pacharapha, T., 2012, 'Knowledge acquisition: The roles of perceived value of knowledge content and source', Journal of Knowledge Management 16(5), 724-739. http://dx.doi.org/10.1108/13673271211262772

Polanyi, M., 1966, The tacit dimension, Routledge and Kegan, London.

Remenyi, D. \& Williams, B., 1998, Doing research in business and management: An introduction to process and method, Sage Publications, London. http://dx.doi. org/10.4135/9781446280416

Rogers, E.M., 1995, Diffusion of innovation, Free Press, New York.

Salmon, G., 2002, E-tivities: The key to active online learning, Routledge Falmer, London.

Schuima, G., 2012, 'Managing knowledge for business performance improvement', Journal of Knowledge Management 16(4), 515-522. http://dx.doi. org/10.1108/13673271211246103

Silva, L.C.S., Kovaleski, J.L., Gaia, S., De Matos, S.A. \& De Francisco, A.C., 2012, 'The challenges faced by Brazil's public universities as a result of knowledge transfer barriers in building the technological innovation center', African Journal of Business Management 6(41), 10547-10557. http://dx.doi.org/10.5897/ AJBM12.315 
Sowe, S.K., Stamelos, I. \& Angelis, L., 2008, 'Understanding knowledge sharing activities in free/open source software projects: An empirical study' Journal of activities in free/open source software projects: An empirical study', Journal of
Systems and Software 81, 431-446. http://dx.doi.org/10.1016/j.jss.2007.03.086

Statistics South Africa, 2010 'Quarterly labour force survey, quarter 1, 2010', Stats SA Library Cataloguing-in-Publication (CIP) Data.

Strauss, A.L. \& Corbin, J.M., 1997, Grounded theory in practice, Sage Publications, Thousand Oaks.

Tonkin, H., Pfeiffer, H.D. \& Tourte, G., 2012, 'Twitter, information sharing and London riots?', Bulletin of the American Society for Information Science and Technology 38(2), 49-57. http://dx.doi.org/10.1002/bult.2012.1720380212

Wang, C., Yang, H. \& Chou, S.T., 2008, 'Using peer-to-peer technology for knowledge sharing in communities of practices', Decision Support Systems 45, 528-540. http://dx.doi.org/10.1016/j.dss.2007.06.012
Wenger, E. \& Snyder, W., 2000, 'Communities of practice: The organizational frontier' Harvard Business Review 79(1), 139-145.

World Wide Worx, 2012, Social media breaks barriers in SA, viewed 25 November 2012, from http://www.worldwideworx.com/socialmedia2012/

World Wide Worx, 2014, WhatsApp takes SA by storm, viewed 10 March 2014, from http://www.worldwideworx.com/whatsapp/

Zhu, C., Valke, M. \& Schellens, T., 2009, 'A cross-cultural study of online collaborative learning', Multicultural Education \& Technology Journal 3(1), 33-46. http://dx.doi. org $/ 10.1108 / 17504970910951138$

Ziemba, E., Papaj, T., \& Zelazny, R., 2013, 'New perspectives on information society: The maturity of research on a sustainable information society', Online Journal of Applied Knowledge Management 1(1), 52-71. 